\title{
Perceptions of academics in Nigerian higher education institutions on graduate attributes in computing disciplines that are desirable for employability and entrepreneurship in Nigeria
}

\author{
Bashiru Lawal*, Aliyu S. Rafi, Bashir Idris and Agunlejika Aderogba Joseph \\ Department of Computer Science, Federal College of Education (Technical) Gusau - Nigeria.
}

Global Journal of Engineering and Technology Advances, 2021, 08(01), 019-027

Publication history: Received on 01June 2021; revised on 04July 2021; accepted on 07July 2021

Article DOI: https://doi.org/10.30574/gjeta.2021.8.1.0097

\begin{abstract}
This study sought to determine the computing disciplines' graduate attributes that are perceived as most important by academics of Nigerian Higher Education Institutes (HEIs) to make graduates in computer related disciplines desirable to potential employers and entrepreneurship in Nigeria. The descriptive survey research design was adopted. One hundred and Fifty (150) academic staff of computer related disciplines across the HEIs (Universities, Polytechnics and Colleges of Education) in the North-Western Nigeria were screened and used through convenience random and purposive sampling methods. The Computing Disciplines' Graduate Attributes Scale (CDGAS) $(r=0.90)$ was the research instrument used in gleaning the field data. Three research questions were raised and one hypothesis formulated, tested and analyzed using Pearson Product Moment Correlation (PPMC). The findings revealed that effective communication skills, leadership quality, collaboration and teamwork, lifelong learning skills, cognitive ability and practical skills, ability to apply knowledge to solving theoretical and practical problems creativity and innovative thinking are the most important computing discipline' graduate attributes that are desirable for graduate employability and entrepreneurship in Nigeria. Also, result from hypothesis testing showed no significant relationship between computing discipline graduate attributes desirable for employability and that of entrepreneurship in Nigeria $(r=0.622$; $\mathrm{P}<0.05)$. Conclusively, the study recommended that career development support efforts should be included in the curriculum, which will focus on helping prospective graduate in computing related discipline on how graduate attributes can hinder or increase their employability and entrepreneurship strengths.
\end{abstract}

Keywords: Graduateness; Graduate Attributes; Employability and Entrepreneurship

\section{Introduction}

The extent to which higher education is capable of producing potential employable and efficient entrepreneurial graduates in the competitive 21st century world is attracting the attention of scholars and policymakers globally. This interest stems from two major concerns. First, there are signs that patterns of work are rapidly changing with new sectors emerging, and with technology, globalization and demographic changes significantly reforming the workforce [17],[19]. The second concern is that the existing university curriculum is not producing graduates with the kind of professional and lifelong learning skills that they need in order to be successful in the competitive and congested changing world of work [13].

The implication of this change is that it is no longer enough for graduates to have a good degree but they should also possess the skills and attributes required to compete and collaborate in a dynamic knowledge economy and world of work [13]. It is therefore clear that the labour market has become competitive and flexible. These changes have been

*Corresponding author: Bashiru Lawal; E-Mail: blawal3119@gmail.com, bash3119@yahoo.com

Department of Computer Science, Federal College of Education (Technical) Gusau - Nigeria. 
caused by the expansion of higher education provision, globalization, and the expansion of the global economy, which are influencing the hiring needs. To this end, universities and students alike have become aware of the changing nature of employment patterns, and are working to incorporate employability attributes in degree programme provision [5\}.

In Nigeria, HEIs have been recognized for their role in pertinent workforce training for the benefit of learners and the community [2],[7]. However today, many of the graduates in the country are perceived to lack the skills needed by the employers of labour [11]. The high rate of unemployment in Nigeria is not because there are no jobs but because there are no competent graduates to do the jobs [21]. Also, the alarming rate of unemployment in the country is not unconnected to the nature and the focus of the training offered by Nigerian tertiary institutions (e.g. universities), which are not in tune with the needs of the society [18]. This realization has led to studies to determine what employability attributes are sought after by employers in a given context.

Researchers across the globe have conducted studies to ascertain the perception of graduate employability and entrepreneurship stakeholders (i.e higher education institutes, employers, lecturers and students/graduates) to determine graduate attributes that are important for employment (e.g. [1], [23], [14]). Many of these studies have focused on individual stakeholders (e.g [23]), some on combination of two or three [1] and others a combination of the four types of stakeholder. In addition, studies conducted on graduate attributes for employability are generic and mostly resulted in conflict pronouncement, which are not empirically justified.

Although, graduate employability stakeholders in Nigeria have raised concerns about the lack of employability attributes in graduates, no study has investigated the issue of the employability attributes that are important for career specific discipline; those attributes that should be included in carrier specific curriculum that will make an effective graduate entrepreneur; and those in which graduates of a particular discipline need more training. Therefore, the aim of this research is to investigate and analyse the graduate attributes that are most desirable for employability and entrepreneurship in Nigeria, as perceived by lecturers of HEIs, using the discipline of computing as a case. The study argues that assessing the most desirable graduate attributes for employability and entrepreneurship for computer related discipline will provide insights that will enhance the HEIs to boost the employability and entrepreneurship prospects of computing discipline graduates in Nigeria.

In exploring the topic of graduate attributes for employability and entrepreneurship, it is useful to briefly review the related literature on the concepts of graduateness and graduate attributes in relation to employability and entrepreneurship.

\section{Graduateness and Graduate Attributes}

The term graduate does not imply a particular type of qualification but rather the exit level of the qualification, be it a degree or diploma. Graduateness is concerned with a set of qualities that marks a person who has undertaken a type of degree or diploma [12]. Graduate attributes on the other hand form a set of individually-assessable outcomes that are the components indicative of the graduate's potential to acquire competence to practice at the appropriate level [10]. The graduate attributes are exemplars of the attributes expected of graduate from an accredited programme. They are clear, succinct statements of the expected capability, qualified if necessary by a range indication appropriate to the type of programme.

The graduate attributes do not, in themselves, constitute an "international standard" for accredited qualifications but provide a widely accepted common reference for bodies to describe the outcomes of substantially equivalent qualifications [10].

In the views of [4], graduate attributes as the attributes that graduates have acquired at university in addition to discipline-specific knowledge, which may be applied to varied contexts. HEIs across the globe have a multitude of lists of skills expected of or suggested for graduates. The categorization of these skills also appears to be inexhaustible [20]. In most cases, these terms are used interchangeably to refer to graduate employability [22].

\section{Employability and Entrepreneurship}

There is no universally acceptable definition for employability. However, a review of the literature suggests that employability is about work and the ability to be employed [9]. This ability depends on "the combination of factors (personal attributes and competences, marketability and economic context), which enable individuals to progress towards or get into employment, to stay in employment and to progress during career" [6]. Thus, employment and 
employability are two sides of the same equation. Whereas employment depends on the demand side, employability seems to be supply-centered.

Within this new context, entrepreneurship has been conceptualized as a competence (EntreComp) in a wider framework "understood as a transversal key competence applicable by individuals and groups, including existing organizations, across all spheres of life" [3]. This broad concept "enables citizens to nurture their personal development, to actively contribute to social development, to enter the job market as employee or as self-employed" [3]. Thus, entrepreneurship and entrepreneurial learning have become part of the strategy to solve the unemployment situation by giving job-seekers an opportunity for development and learning to adapt to this new uncertain scenario. It also provides better clues on how to deal with employability and the roles of youth work and other stakeholders.

\section{Problem Statement}

A good number of researches have been conducted globally to ascertain the perception of graduate employability stakeholders on issues concerning the graduate attributes that will make graduate desirable to potential employers and entrepreneurship. Many of these studies have focused on individual stakeholders and some on combination of more than one stakeholder. However, most of what have been reported in literature to determine the graduate attributes desirable for employability are discipline-generic and mostly resulted in conflict pronouncement, which are not empirically justified. Although, graduate employability stakeholders in Nigeria have raised concerns about the lack of employability attributes in graduates, no study has investigated the employability attributes that are desirable for career specific discipline and those attributes that should be included in carrier specific curriculum that will make an effective graduate entrepreneur. These are the problems to be addressed in this study. In addition, relationship between the graduate attributes desirable for employability and that of entrepreneurship are also determined.

\subsection{Purpose of the Study}

The study tried to:

- Determine the computing disciplines' graduate attributes that are perceived as most important by academics of Nigerian HEIs to make graduates in computer related disciplines desirable to potential employers in Nigeria

- Determine the computing disciplines' graduate attributes that are perceived as most desirable by academics to make an effective graduate entrepreneur in computer related discipline in Nigeria

- Determine the relationship between the attributes determinant for employability and entrepreneurship

\subsection{Research Questions}

The following research questions guided the study:

- What graduate attributes in computing discipline do academics of Nigerian HEIs consider most important to make graduates in computer related disciplines desirable to potential employers?

- What graduate attributes in computing discipline do academics of Nigerian HEIs consider most important to make an effective graduate entrepreneur in computer related discipline in Nigeria?

- Is there any difference between the graduates attributes in computing discipline desirable for graduate employability and that of entrepreneurship in Nigeria?

\subsection{Research Hypothesis}

The null hypothesis formulated and tested at 0.05 for the research is:

Ho: There is no significant difference between the graduates attributes in computing discipline desirable for graduate employability and that of entrepreneurship

\subsection{Research Methodology}

The study adopted descriptive survey design. The population for the study comprised of all academic staff in computer related discipline in all the higher education institutes across the North-Western zone of Nigeria. A combined sampling technique comprising: stratified, convenience and purposive sampling was used to draw a sample of 180 respondents from higher education institutes across the study zone. 
The instruments used for data collection was a 20 - item questionnaire. The instrument was face validated by three research experts from three different HEIs from the region of study. The reliability of the instruments was determined using Cronbach Alpha and a reliable coefficient of 0.89 obtained. 150 out of the 180 administered questionnaires were correctly filled and returned giving a return rate of $83.33 \%$. Regarding the decision rule, any questionnaire item with a mean value of 2.50 or above was interpreted as mostly important response of such item while a mean score below 2.50 indicates a least important response for the item. Mean statistic was used to answer the research questions while hypothesis was tested at 0.05 level of significance using Pearson Product Moment Correlation (PPMC).

\section{Results}

\section{Research Question 1}

What graduate attributes in computing discipline do academics of HEIs consider as important to make graduates in computer related disciplines desirable for entrepreneurship in Nigeria?

Results presented in the Table 1a showed that academics in Nigerian higher education institutes attributed high level desirability for employability to graduate attributes: Communication effectively using visual, mathematical and or language skills for employability having Mean \& SD scores of 3.561 and 1.554 respectively.

Other graduate attributes that were perceived to be of high importance for employability are: Leadership quality, collaboration and teamwork (3.555 \& 1.552); Cognitive ability and skills in practical skills relating to solution of mathematical problems and its application (3.548 \& 1.550); Creativity and innovative thinking (3.531 \& 1.501); Ability to apply knowledge to solving theoretical and practical problems in other related area in relation to national and societal needs (3.321 \& 1.501); Attention to rigorous thinking: knowledge and understanding of modelling and design (3.321 \& $1.500)$, Lifelong learning skills (3.321 \& 1.500) and Self-management of learning development, time and organizational skills (3.012 \& 1.498).

Also, academics reported a moderate level of desirability to graduate attributes such as: Adaptability and flexibility (2.589 \& 1.488); Analytical thinking (2.589 \& 1.490); Interpersonal skills (2.963 \& 1.497); Capacity to future focused ( 2.558 \& 1.447); Capacity to business orientation (2.558 \& 1.446); Critical evaluation and testing (2.729 \& 1.465); and Resilient in the face of obstacles (2.528 \& 1.451). However, low level of desirability for employment was reported for graduate attributes: Teaching skills; Internet surfing skills and Proficiency in social media application with Mean \& S.D scores of $2.259 \& 1.399 ; 2.259 \& 1.199$ and $2.230 \& 1.342$ respectively.

Table 1 Graduate Attributes in Computing Discipline Desirable for Employability in Nigeria

\begin{tabular}{|c|c|c|c|c|c|c|}
\hline $\mathbf{S} / \mathbf{N}$ & Graduate Attributes & $\mathbf{F}$ & $\mathbf{N}$ & Mean & S.D & Decision \\
\hline 1 & $\begin{array}{l}\text { Communication effectively using visual, mathematical } \\
\text { and or language skills }\end{array}$ & 143 & 150 & 3.561 & 1.554 & Desirable \\
\hline 2 & $\begin{array}{l}\text { Using and displaying creative thinking for responsible } \\
\text { problem solving }\end{array}$ & 133 & 150 & 3.522 & 1.498 & Desirable \\
\hline 3 & Creativity and innovative thinking & 139 & 150 & 3.531 & 1.501 & Desirable \\
\hline 4 & Leadership quality, collaboration and teamwork & 141 & 150 & 3.555 & 1.552 & Desirable \\
\hline 5 & $\begin{array}{l}\text { Cognitive ability and skills in practical skills relating to } \\
\text { solution of mathematical problems and its application }\end{array}$ & 140 & 150 & 3.548 & 1.550 & Desirable \\
\hline 6 & Lifelong learning skills & 133 & 150 & 3.321 & 1.500 & Desirable \\
\hline 7 & $\begin{array}{l}\text { Self-management of learning development, time and } \\
\text { organizational skills }\end{array}$ & 122 & 150 & 3.012 & 1.498 & Desirable \\
\hline 8 & Teaching skills & 67 & 150 & 2.259 & 1.399 & Low \\
\hline 9 & $\begin{array}{l}\text { Ability to apply knowledge to solving theoretical and } \\
\text { practical problems in other related area in relation to } \\
\text { national and societal needs }\end{array}$ & 133 & 150 & 3.321 & 1.501 & Desirable \\
\hline
\end{tabular}




\begin{tabular}{|c|l|c|c|c|c|c|}
\hline 10 & Adaptability and flexibility & 92 & 150 & 2.589 & 1.488 & Moderate \\
\hline 11 & Internet surfing skills & 67 & 150 & 2.259 & 1.399 & Low \\
\hline 12 & Research skills & 129 & 150 & 3.116 & 1.499 & Desirable \\
\hline 13 & $\begin{array}{l}\text { Attention to rigorous thinking: knowledge and } \\
\text { understanding of modelling and design }\end{array}$ & 133 & 150 & 3.321 & 1.500 & Desirable \\
\hline 14 & $\begin{array}{l}\text { Programming Proficiency in several programming } \\
\text { languages }\end{array}$ & 112 & 150 & 2.969 & 1.497 & Moderate \\
\hline 15 & Analytical thinking & 100 & 150 & 2.899 & 1.490 & Moderate \\
\hline 16 & Resilient in the face of obstacles & 79 & 150 & 2.528 & 1.451 & Moderate \\
\hline 17 & Interpersonal skills & 111 & 150 & 2.963 & 1.497 & Moderate \\
\hline 18 & Organizational skills & 112 & 150 & 2.969 & 1.497 & Moderate \\
\hline 19 & Developing entrepreneurial opportunities & 120 & 150 & 3.006 & 1.498 & Desirable \\
\hline 20 & Capacity to business orientation & 83 & 150 & 2.558 & 1.446 & Moderate \\
\hline 21 & Capacity to future focused & 83 & 150 & 2.558 & 1.447 & Moderate \\
\hline 22 & User focused & 75 & 150 & 2.510 & 1.440 & Moderate \\
\hline 23 & Attainment to engineering principles & 112 & 150 & 2.973 & 1.498 & Moderate \\
\hline 24 & Proficiency in social media application & 66 & 150 & 2.230 & 1.427 & Low \\
\hline 25 & Critical evaluation and testing & 95 & 150 & 2.729 & 1.465 & Moderate \\
\hline
\end{tabular}

\section{Research Question 2}

What graduate attributes in computing discipline do academics of HEIs consider as important to make graduates in computer related disciplines desirable for entrepreneurship in Nigeria?

Results presented in the Table 2 showed that academics in Nigerian higher education institutes attributed high level desirability for entrepreneurship to graduate attributes: Creativity and innovative thinking (3.721 \& 1.581); Developing entrepreneurial opportunities (3.723 \& 1.598); Capacity to business orientation (3.722 \& 1.586); Using and displaying creative thinking for responsible problem solving (3.722 \& 1.582) and Capacity to future focused (3.722 \& 1.586$)$.

Other graduate attributes that were perceived to be of high desirability for entrepreneurship are: Communication effectively using visual, mathematical and or language skills for employability having (3.721 \& 1.584); Leadership quality, collaboration and teamwork (3.721 \& 1.582); Cognitive ability and skills in practical skills relating to solution of mathematical problems and its application (3.721 \& 1.580); Ability to apply knowledge to solving theoretical and practical problems in other related area in relation to national and societal needs (3.722 \& 1.589); Adaptability and flexibility (3.722 \& 1.588); Attention to rigorous thinking: knowledge and understanding of modelling and design (3.321 $\& 1.500)$, Lifelong learning skills (3.720 \& 1.570).

Also, academics reported a moderate level of desirability to graduate attributes such as: Interpersonal skills (2.963 \& 1.497); Organizational skills (2.969 \& 1.497) and Critical evaluation and testing (2.729 \& 1.465). However, low level of desirability for entrepreneurship was reported for graduate attributes: Teaching skills, Internet surfing skills and Proficiency in social media application with Mean \& S.D scores of 2.259 \& 1.399; $2.259 \& 1.199$ and 2.230 \& 1.342 respectively. 
Table 2 Graduate Attributes in Computing Discipline Desirable for Entrepreneurship in Nigeria

\begin{tabular}{|c|c|c|c|c|c|c|}
\hline $\mathrm{S} / \mathrm{N}$ & Graduate Attributes & $\mathbf{F}$ & $\mathbf{N}$ & Mean & S.D & Decision \\
\hline 1 & $\begin{array}{l}\text { Communication effectively using visual, mathematical and } \\
\text { or language skills }\end{array}$ & 141 & 150 & 3.721 & 1.584 & Desirable \\
\hline 2 & $\begin{array}{l}\text { Using and displaying creative thinking for responsible } \\
\text { problem solving }\end{array}$ & 147 & 150 & 3.722 & 1.582 & Desirable \\
\hline 3 & Creativity and innovative thinking & 145 & 150 & 3.721 & 1.581 & Desirable \\
\hline 4 & Leadership quality, collaboration and teamwork & 141 & 150 & 3.721 & 1.582 & Desirable \\
\hline 5 & $\begin{array}{l}\text { Cognitive ability and skills in practical skills relating to } \\
\text { solution of mathematical problems and its application }\end{array}$ & 145 & 150 & 3.721 & 1.580 & Desirable \\
\hline 6 & Lifelong learning skills & 140 & 150 & 3.720 & 1.570 & Desirable \\
\hline 7 & $\begin{array}{l}\text { Self-management of learning development, time and } \\
\text { organizational skills }\end{array}$ & 145 & 150 & 3.724 & 1.588 & Desirable \\
\hline 8 & Teaching skills & 67 & 150 & 2.259 & 1.399 & Low \\
\hline 9 & $\begin{array}{l}\text { Ability to apply knowledge to solving theoretical and } \\
\text { practical problems in other related area in relation to } \\
\text { national and societal needs }\end{array}$ & 145 & 150 & 3.722 & 1.589 & Desirable \\
\hline 10 & Adaptability and flexibility & 142 & 150 & 3.722 & 1.588 & Desirable \\
\hline 11 & Internet surfing skills & 67 & 150 & 2.259 & 1.199 & Low \\
\hline 12 & Research skills & 129 & 150 & 3.116 & 1.499 & Desirable \\
\hline 13 & $\begin{array}{l}\text { Attention to rigorous thinking: knowledge and } \\
\text { understanding of modelling and design }\end{array}$ & 120 & 150 & 3.321 & 1.500 & Desirable \\
\hline 14 & $\begin{array}{l}\text { Programming Proficiency in several programming } \\
\text { languages }\end{array}$ & 112 & 150 & 2.969 & 1.497 & Moderate \\
\hline 15 & Analytical thinking & 129 & 150 & 3.117 & 1.560 & Desirable \\
\hline 16 & Resilient in the face of obstacles & 122 & 150 & 3.108 & 1.551 & Desirable \\
\hline 17 & Interpersonal skills & 99 & 150 & 2.963 & 1.497 & Moderate \\
\hline 18 & Organizational skills & 100 & 150 & 2.969 & 1.497 & Moderate \\
\hline 19 & Developing entrepreneurial opportunities & 147 & 150 & 3.723 & 1.598 & Desirable \\
\hline 20 & Capacity to business orientation & 144 & 150 & 3.722 & 1.586 & Desirable \\
\hline 21 & Capacity to future focused & 111 & 150 & 3.358 & 1.547 & Desirable \\
\hline 22 & User focused & 143 & 150 & 3.710 & 1.580 & Desirable \\
\hline 23 & Attainment to engineering principles & 143 & 150 & 3.711 & 1.579 & Desirable \\
\hline 24 & Proficiency in social media application & 66 & 150 & 2.230 & 1.342 & Low \\
\hline 25 & Critical evaluation and testing & 95 & 150 & 2.729 & 1.465 & Moderate \\
\hline
\end{tabular}

\section{Research Question 3}

Is there any difference between the graduates attributes in computing discipline desirable for graduate employability and that of entrepreneurship? 
Table 3 Correlation between Graduate Attributes in Computing Discipline for Employability and Entrepreneurship in Nigeria

\begin{tabular}{|l|c|c|c|c|}
\hline \multicolumn{1}{|c|}{ Variables } & N & Mean & S.D & R Significant Level \\
\hline $\begin{array}{l}\text { Computing Discipline' Graduate Attributes Desirable for } \\
\text { Employability }\end{array}$ & 150 & 3.109 & 1.598 & \\
\hline $\begin{array}{l}\text { Computing Discipline' Graduate Attributes Desirable for } \\
\text { Entrepreneurship }\end{array}$ & 150 & 3.111 & 1.593 & $0.623 .0000^{*}$ \\
\hline
\end{tabular}

The hypothesis ( $\left.\mathrm{H}_{0}\right)$ designed for the research was used to answer the research question 3 above.

Ho: There is no significant difference between the graduates attributes in computing discipline desirable for graduate employability and that of entrepreneurship in Nigeria

Table 3 shows that there is significant relationship between Computing Discipline' Graduate Attributes Desirable for Employability and that of Entrepreneurship in Nigeria. Hence, the null hypothesis is rejected. The coefficient $r=0.623$; $\mathrm{P}<0.05$ implies that same sets of graduate attributes for computer related discipline desirable for employability are required make an effective graduate entrepreneur in Nigeria.

\section{Discussion and Findings}

Research question 1 asks "What graduate attributes in computing discipline do academics of Nigerian HEIs consider as important to make graduates in computer related disciplines desirable for employability in Nigeria?" The findings revealed that most important computing discipline graduate attributes for employability are: Communication effectively using visual, mathematical and or language skills, Leadership quality, collaboration and teamwork, Lifelong learning skills, Cognitive ability and skills in practical skills relating to solution of mathematical problems and its application, Ability to apply knowledge to solving theoretical and practical problems in other related area in relation to national and societal needs, Creativity and innovative thinking and Using and displaying creative thinking for responsible problem solving. The findings is line with [16] \& [8], who conducted an employer satisfaction research and found out that employers were looking for transformative potential in graduates and they highlighted the following important graduate attributes: knowledge; a willingness to learn; the ability to work in a modern organization; interpersonal skills and communication. In this regard, it is no longer enough for graduates to have a good degree but they should also possess the skills and attributes required to compete and collaborate in a dynamic knowledge economy.

Research question 2 asks "What graduate attributes in computing discipline do academics of Nigerian HEIs consider as important to make graduates in computer related disciplines desirable for entrepreneurship in Nigeria?" The findings show that graduate attributes that are desirable to produce successful graduate entrepreneur in computer related field are: all the attributes identified as desirable for graduate employability. Others are: Capacity to business orientation; developing entrepreneurial opportunities; using and displaying creative thinking for responsible problem solving and capacity to future focused.

In addition, the null hypothesis designed for the study and used to answer research question 3 says: there is no significant difference between the graduates attributes in computing discipline desirable for graduate employability and that of entrepreneurship in Nigeria. The finding shows that there was statistical significant relationship between the computing discipline graduates attributes desirable for graduate employability and that of entrepreneurship in Nigeria. The interpretation of this finding revealed that computing discipline' graduate attributes that are desirable for graduate employability are same for graduate entrepreneurship.

\section{Recommendations}

The following recommendations are made

- Career development support efforts should be included in the computing discipline curriculum in the Nigerian HEIs, which will focus on helping prospective graduate in computing related discipline on how graduate attributes can hinder or increase their employability and entrepreneurship strengths. 
- There is the need to establish career development support centres in all the HEIs in Nigeria that will help students and prospective graduates become more aware of their career interests and motivations, their employability strengths and entrepreneurship development areas.

\section{Conclusion}

On the basis of the findings of this study it was concluded that

- Effective communication skills; leadership quality; collaboration and teamwork ability, lifelong learning skills, cognitive ability and practical skills, ability to apply knowledge to solving theoretical and practical problems; creativity and innovative thinking and time management skills are the most important computing discipline' graduate attributes that are desirable for graduate employability and entrepreneurship in Nigeria

- There was no significant difference between the computing discipline' graduate attributes desirable for employability and that of entrepreneurship in Nigeria. Thus, computing discipline' graduate attributes that required by employer of labours are same set of attributes that will make a successful computing related entrepreneurs in Nigeria

- Also the study provided insights that can be useful for addressing the employability and entrepreneurship needs of computing discipline graduates in Nigeria

- Another significant conclusion was that HEIs in Nigeria should be aware of the findings of this study and how the identified graduate attributes relate to graduate employability strengths and entrepreneurship development areas.

\section{Compliance with ethical standards}

\section{Acknowledgments}

We sincerely appreciate the cooperation and active participation of our research participants, the academic staffs in all the participating Higher Education Institutions across the North-Western Nigeria.

We also extend our heartfelt gratitude and appreciation to the Federal Government of Nigeria as the source of the research grant for this research through the Tertiary Education Trust Fund (TETFUND) in Nigeria for the Institution Based Academic Research (IBR) merged - 2017/2019

\section{Disclosure of conflict of interest}

There was no conflict of interest amongst the authors

\section{Statement of ethical approval}

Ethical Approval granted by the Research and ethics committee of the Federal College of Education (Technical) Gusau Zamfara State Nigeria

\section{References}

[1] Ahmadl E, Padii S, Hassan S. Perception lecturers of the soft skills of engineering students in Malaysian Polytechnics. Multidisciplinary Studies. 2015; 2: 487-495.

[2] Agabi O. Obasi K, Ohia A. Academic program development and the participation of relevant interest groups for quality manpower production in Nigeria higher education. World Journal of Education. 2012; 2(3): 87.

[3] Bacigalupo M, Kampylis P, Punie Y, Van den Brande G. EntreComp: The Entrepreneurship Competence Framework, Luxembourg: Publication Office of the European Union. 2016.

[4] Barrie SC. Understanding what we mean by the generic attributes of graduates. Sydney: University of Sydney. 2006.

[5] Cai Y. Graduate employability: A conceptual framework for understanding employers' perceptions. Higher Education. 2013; 65(1): 457-469.

[6] CEDEFOP. Terminology of European education and training policy-a selection of 100 key terms. Luxembourg: Office for Official Publications of the European Communities. 2008. 
[7] FRN. National Policy on Education. Lagos. 2004.

[8] Harvey and Knight Transforming Higher Education, Society for Research into Higher Education, Buckingham. 1996.

[9] Hillage J, Pollard E. Employability: developing a framework for policy analysis. Research Report RR85, Department for Education and Employment. 1998.

[10] International Engineering Alliance. Graduate Attributes and Professional Competencies. 21 June $2013 ; 3$.

[11] Jimoh K, BtMohd Y, Venloo. Relationship between the Curriculum and Attributes of Nigerian Faculty of Education Graduates towards Teaching in Kwara State, Nigeria. African Higher Education Review (AHER). 9 (1\&2). September 2015.

[12] Kroeze J H, Ponelis SR, Venter IM, Pretorius P D, Prinsloo P. Aligning African Computing Disciplines' Graduate Attributes with International Standards, Published in: Proceedings of the 6th International Multi-conference on Society, Cybernetics and Informatics (IMSCI 2012), Orlando, Florida, USA. 17-20 July 2012; 70-75,

[13] Lees D. Information for Academic Staff on Employability, University of Exeter. LTSN Generic Centre. 2002.

[14] Morrison A. A class act? Lecturers' views on undergraduates' employability. British Journal of Sociology of Education. 2014; 35(4): 487-505.

[15] Newton J. Learning and Teaching: Enhancing Student Achievement through Employability. Thailand European Policy Dialogue Support Facility. 2015.

[16] MWAIS. The Multi-disciplinary Nature of IT Research\& Practice, Sixth Midwest Association for Information Systems Conference, Omaha, NE. 20-21 May 2011.

[17] Oliver B. Redefining graduate employability and work-integrated learning: Proposals for effective higher education in disrupted economies. Journal of Teaching and Learning for Graduate Employability. 2015;6(1): 5665.

[18] Okojie J. Why Nigerian graduates are not employable. Punch newspaper.2013.

[19] Pitan OS. An assessment of generic skills demand in five sectors of the Nigerian labour market. Public and Municipal Finance. 2015; 4(1): 28-36.

[20] Shivoro R S, Shalyefu R K, Kadhila N. Perspectives on graduate employability attributes for management sciences graduates. South African Journal of Higher Education. 2018; 32(1): 216-232.

[21] Soludo CC. The university, citizenship and national development in Nigeria. A founder's day lecture delivered at American University of Nigeria (AUN), Yola. The Eagle online. 2012.

[22] Tempone I, MarieK, NaomiS, Phil H, BryanH, Jenny K. Desirable generic attributes for accounting graduates into the twenty-first century: The views of employers. Accounting Research Journal. 2012; 25(1): 41-55.

[23] Wimalasiri H S. Employer's perception on employability skills and attitudes of new graduates. Qualitative insights from the employers in Sri Lanka Hashan. Asian Journal of Multi disciplinary Studies. 2015; 3(11): 112-120. 